ТЕОРЕТИЧНЕ ОБҐРУНТУВАННЯ ПЕДАГОГІЧНИХ УМОВ ФОРМУВАННЯ ГОТОВНОСТІ ДО УСВІДОМЛЕНОГО БАТЬКІВСТВА СТУДЕНТІВ ЗАКЛАДІВ ВИЩОЇ ОСВІТИ

\title{
THEORETICAL FOUNDATION OF PEDAGOGICAL CONDITIONS OF THE FORMATION OF READYNESS FOR THE CONSCIOUS PATERNITY OF STUDENTS OF HIGHER EDUCATION INSTITUTIONS
}

у статті доведено актуальність проблеми фоормування готовності до усвідомленого батьківства студентів закладів вищої освіти. Уточнено, в чому саме полягає усвідомленість батьківства. Визначено суть понять «усвідомлене батьківство» $i$ «готовність до усвідомленого батьківства», надано їх характерні ознаки, з'ясовано, що кожен із цих френоменів є системним утворенням, виокремлено їх структурні компоненті та складники.

Доведено, що для успішного вирішення вказаної проблеми важливим є створення певних педагогічних умов. Підкреслено. що під педагогічними умовами мається на увазі сукупність зовнішніх обставин, які забезпечують результативне формування готовності до усвідомленого батьківства. Теоретично обгрунтовано педагогічні умови формування готовності до усвідомленого батьківства студентів закладів вищої освіти.

З'ясовано, що першою умовою реалізації зазначеної проблеми є організація цілеспрямованої підготовки викладачів закладів вищої освіти до формування готовності до усвідомленого батьківства студентів. Зазначено ключові аспекти та зміст чієї підготовки в межах когнітивного, мотиваційного та поведінкового складників, розглянуто особливості кожного з цих компонентів. Розкрито сутність другої умови, яка полягає у створенні й реалізації на практиці науковометодичного забезпечення з фрормування готовності до усвідомленого батьківства студентів закладів вищої освіти. Встанов лено, що реалізація цієї умови є необхідним кроком для успішного здійснення діяльності з формування в студентів готовності до усвідомленого батьківства в межах когнітивного, емоційного, мотиваційного та поведінкового складників всіх його компонентів. Вказано, що третьою умовою успішного формування зазначеної готовності $є$ спонукання студентів до здійснення систематичного самовиховання. З'ясовано, що важливість цієї умови пов'язана з динамічною структурою готовності до усвідомленого батьківства та ії змінюваністю під впливам таких зовнішніх фоакторів, як соціальні норми, інфрормаційний простір, статеві відносини, вагітність тощо. Підкреслено, що ефективність формування готовності до усвідомленого батьківства підвищується за умови систематичної діяльності з боку студента в цьому напрямі.

Ключові слова: батьки, батьківство, усвідомлене батьківство, готовність до усвідомленого батьківства, дитячо-батьківські стосунки, педагогічні умови.
The article proves the urgency of the problem of forming readiness for conscious paternity of students of higher education institutions. It was clarified what exactly is the essence of paternity. The essence of the concepts "conscious paternity" and "readiness for the conscious paternity" has been determined and their characteristic features have been given. It was found that each of these phenomena is a systemic formation, their structural components and constituents were distinguished.

It was proved that for the successful solution of the mention problem the creation of certain pedagogical conditions is important. It was underlined that by the pedagogical conditions we mean a set of external circumstances that ensure the effective formation of readiness for conscious paternity. The pedagogical conditions for the formation of readiness for conscious paternity of students of higher education institutions have been theoretically substantiated in the article.

It was also found that the first condition for the implementation of this problem is the organization of targeted training of teachers of higher education institutions to form a readiness for conscious paternity of students. The key aspects and the content of this training within the cognitive, motivational and behavioral components are outlined and the features of each of these components are considered.

The essence of the second condition, that consists in the creation and implementation in the practice of scientific and methodological support for the formation of readiness for conscious paternity of students of higher education. It has been established that the implementation of this condition is a necessary step for the successful implementation of activities for the formation of students' readiness for conscious paternity within the cognitive, emotional, motivational and behavioral components of all its components. It was indicated that the third condition for the successful formation of this readiness is to encourage students to carry out systematic self-education.

It was also explained that the importance of this condition is related to the dynamic structure of readiness for conscious paternity and its variability under the influence of such external factors as social norms, information space, sexual relations, pregnancy, etc. It has been emphasized that the effectiveness of the formation of readiness for conscious paternity increases with the systematic activities of the student in this direction. Key words: parents, paternity, conscious paternity, readiness for the conscious paternity, childparent relations, pedagogical conditions. педагогічного університету імені Г.С. Сковороди

Постановка проблеми в загальному вигляді. Сучасний етап розвитку суспільства характеризується трансорормацією поглядів на батьківство. Зміна вимог до виховання дітей і здійснення батьківських фрункцій зумовлює необхідність розробки нових підходів до фрормування в молоді готовності до батьківства.

Актуальність зазначеної тематики посилюється наявністю суперечностей між потребою держави в підвищенні соціального стану сім'ї, її педагогіч- 
ного потенціалу та слабким використанням цього потенціалу в реальній практиці; між зростаючими вимогами суспільства в готовності молоді до батьківства та негативною динамікою в ії становленні; між нагальною потребою закладів вищої освіти в сучасному науково-методичному забезпеченні процесу формування готовності до усвідомленого батьківства студентів і недостатністю відповідних методичних доробок у педагогічній науці.

Одним із шляхів розв'язання перерахованих суперечностей $€$ забезпечення цілеспрямованого формування готовності до усвідомленого батьківства студентів закладів вищої освіти.

Аналіз останніх досліджень і публікацій. Як показав аналіз наукової літератури, сучасні науковці приділяють багато уваги питанню готовності до батьківства. Дослідження проводили С. Асрієва, Д. Бикова, А. Вагапова, О. Васильєва, О. Євдокимова, М. Єрміхіна, Ю. Іванова, А. Ролева тощо.

Серед українських науковців О. Лемещенко займалася вивченням соціально-психологічних умов фрормування у старшокласників готовності до усвідомленого батьківства [8], Л. Повалій досліджувала питання формування відповідального батьківства [12], О. Тіунова вивчала психологічні умови фрормування відповідального ставлення до материнства [13], Р. Хавула займався дослідженням психолого-педагогічних чинників формування психологічної готовності юнаків до батьківства [14]

Виділення не вирішених раніше частин загальної проблеми. Загалом наукові розвідки сучасних вчених висвітлюють різні аспекти досліджуваного френомену, але вивчення педагогічних умов фрормування готовності до усвідомленого батьківства студентів закладів вищої освіти не було окремим об'єктом наукових розробок, що і зумовило вибір теми дослідження.

Мета статті - визначення і теоретичне обґрунтування педагогічних умов фрормування готовності до усвідомленого батьківства студентів закладів вищої освіти.

Виклад основного матеріалу. На попередньому етапі дослідження було визначено, що усвідомленість батьківства полягає в здатності робити усвідомлений вибір бути батьками, сприймати дитину як особистість, як суб'єкта сімейних стосунків з урахуванням її індивідуальних особливостей вже з перших хвилин після її народження, усвідомлено оволодівати знаннями, вміннями та навичками здійснення батьківських функцій.

Характерними ознаками усвідомленого батьківства $€$ відповідальне ставлення до виховання дитини, здатність батька і матері до рефлексії та самоаналізу, вміння спостерігати власні батьківські реакції, сподівання, очікування, переживання. Усвідомлене батьківство є системним утворенням, у структурі якого виокремлюють такі компоненти: батьківське ставлення, батьківськи установки й очікування, батьківські позиції, батьківські почуття, батьківська відповідальність, ціннісні орієнтації та стилі сімейного виховання. Кожен компонент містить емоційний, мотиваційний, когнітивний, поведінковий складники [11, с. 23].

Готовність до усвідомленого батьківства $€$ цілісним, інтегративним, стійким особистісним утворенням, яке включає усвідомленість вибору бути відповідальними батьками та передбачає вдосконалення психічних процесів, станів і властивостей батьків, необхідних для ефективного виховання дитини. Це суб'єкт-суб'єктна позитивна орієнтація батьків на сприйняття і стосунки з майбутньою дитиною, сукупність знань стосовно себе як батьків і вміння використовувати педагогічні засоби і методи взаємодії так, щоб сприяти повноцінному психічному і фрізичному розвитку дитини.

У структурі готовності до усвідомленого батьківства виокремлюють мотиваційний, емоційний, когнітивний і поведінковий компоненти. Мотиваційний компонент поєднує мотиви народження та виховання дитини. Емоційний компонент включає емоційне сприйняття ситуації батьківства, емоційне й оцінювальне ставлення до дитини, фоновий настрій, який супроводжує взаємодію 3 дитиною, рівень задоволеності власною роллю батька чи матері. Когнітивний компонент відображає знання про себе, як особистість, про свій характер, здатність до взаємодії з дитиною на різних стадіях її розвитку. Поведінковий компонент поєднує суб'єкт-суб'єктне позитивне емоційне ставлення до дитини, що спостерігається в сприйнятті стану дитини та реагуванні на вияви цього стану, створенні стійких позитивних дитячо-батьківських стосунків [1, с. 10].

Успішності процесу фрормування готовності до усвідомленого батьківства студентів закладів вищої освіти сприяє створення необхідних педагогічних умов. Під умовами сучасна наука розуміє необхідні обставини, які роблять можливим здійснення чого-небудь [15, с. 632]; зовнішні обставини, від яких залежить щось інше [3, с. 707].

Під педагогічними умовами науковці розуміють зовнішні обставини, пов'язані 3 навчально-виховним процесом, які забезпечують його організацію, розвиток і фрункціювання [6, с. 97]; сукупність зовнішніх і внутрішніх характеристик та параметрів реалізації педагогічного процесу, що впливають на його високу результативність [10, с. 152]; сукупність організаційних форм і методів, матеріальних та змістових можливостей здійснення навчальновиховного процесу, який забезпечує успішність досягнення поставленої мети [2, с. 181].

Науковці виокремлюють два рівні педагогічних умов. Перший пов'язаний з особистісними характеристиками студентів, які зумовлюють успішність навчально-виховного процесу. До другого належать обставини реалізації процесу: зміст та реа- 
лізація діяльності студентів, міжособистісні стосунки, стосунки педагогів зі студентам, взаємодія навчального закладу з навколишнім середовищем тощо [4, с. 136].

У дослідженні під педагогічними умовами розуміється сукупність зовнішніх обставин, які забезпечують результативне фрормування готовності до усвідомленого батьківства студентів закладів вищої освіти. Першою умовою досягнення зазначеної мети є організація цілеспрямованої підготовки викладачів до формування готовності до усвідомленого батьківства студентів закладів вищої освіти.

Структура готовності викладача до професійної діяльності складається 3 когнітивного, мотиваційного і діяльнісного компонентів [7, с. 85]. Когнітивний компонент включає знання з питання усвідомленого батьківства, розуміння мети фрормування у студентів готовності до усвідомленого батьківства, врахування існуючих у навчальному закладі умов для цього, здатність аналізувати результати своєї діяльності.

Мотиваційний компонент складається зі ставлення до здійснення діяльності, прагнення до поглиблення власних знань, напрацювання навичок і здійснення діяльності 3 досягнення мети. Діяльнісний компонент виявляється у використанні отриманих знань та навичок для фрормування готовності до усвідомленого батьківства студентів закладів вищої освіти.

Другою умовою $є$ створення й реалізація на практиці науково-методичного забезпечення фрормування готовності до усвідомленого батьківства студентів закладів вищої освіти. Забезпечення може бути використано щодо навчального середовища, виховного середовища, інформаційного середовища, освітнього простору.

Науково-методичне забезпечення розуміється як сукупність нормативних, програмних, дидактичних і критеріально-оцінювальних матеріалів, спрямованих на підвищення ефективності діяльності. У структурі науково-методичного забезпечення поєднуються бесіди, семінари, зустрічі, лекції, навчальні заняття, тести, опитувальники, процес формування в студентів необхідних компетенцій, технологія навчання педагогічного колективу [9, с. 146]. В межах дослідження науково-методичне забезпечення спрямовано на підтримку процесу формування готовності до усвідомленого батьківства студентів закладів вищої освіти з урахуванням когнітивного, емоційного, мотиваційного та поведінкового складників усіх структурних компонентів усвідомленого батьківства.

Когнітивний складник поєднує знання щодо особливостей фрізичного і психічного розвитку дитини на різних вікових етапах, знання про способи, пріоритетні напрями і мету взаємодії 3 дитиною на кожному з них, уявлення про репродуктивні норми суспільства, відповідальну і без- відповідальну поведінку батьків, розподіл відповідальності між батьками в інших сім'ях [11, с. 403].

Мотиваційний складник включає усвідомлення власного бажання бути батьком чи матір'ю, усвідомлення потреб, спонукань і мотивів, які зумовлюють ступінь бажання студентів мати дітей. Серед основних мотивів зазначають чотири групи: 1) дитина заради дитини; 2) соціальні; 3) духовні; 4) матеріальні $[5$, с. 69].

Емоційний складник виражений в емоційному забарвлені й оціночному ставленні до батьківства, зумовлює ті чи інші переживання й почуття, виступаючи в якості маркеру пріоритетів у питаннях ставлення до себе як до майбутнього батька (матері); оцінки себе з точки зору відповідальності і розподілу ролей у сім'ї; домінуючого емоційного фону, що супроводжує думки про майбутнє батьківство; оцінки й судження щодо різних типів батьківського ставлення; оцінки й думки щодо образу майбутньої дитини та майбутніх дитячо-батьківських стосунків; сукупність поглядів, суджень і позицій особистості щодо кількості дітей у сім'ї.

Поведінковий складник характеризується здатністю до контролю власної поведінки, здійсненням діяльності (чи відмовою ії здійснювати) з оволодіння знаннями, вміннями на навичками взаємодії 3 майбутньою дитиною [11, с. 22].

Третьою умовою фрормування готовності до усвідомленого батьківства студентів закладів вищої освіти є спонукання студентів до здійснення систематичного самовиховання у вказаному напрямі. Важливість втілення цієї умови пояснюється тим, що готовність до усвідомленого батьківства $€$ динамічною структурою, яка постійно змінюється під впливом багатьох фракторів: соціальні норми суспільства, вплив інформаційного простору (телебачення, інтернет, соціальні мережі тощо), уклад життя батьківської сім'ї студента, спілкування 3 однолітками, статеві відносини, незапланована вагітність, пошук партнера для шлюбу, кохання тощо.

Готовність фрормується набагато ефективніше за умови систематичної самовиховної діяльності в зазначеному напрямі. Тому студенти мають здійснювати системну діяльність з формування в себе готовності до усвідомленого батьківства, що дасть можливість зробити ці напрацювання більш стійкими та якісними.

Висновки. Під час проведення дослідження визначено, що формування готовності до усвідомленого батьківства студентів закладів вищої освіти $€$ актуальною проблемою сьогодення. Успішність їі вирішення забезпечує створення таких педагогічних умов: організація цілеспрямованої підготовки викладачів закладів вищої освіти до формування готовності до усвідомленого батьківства студентів закладів вищої освіти; створення й реалізація на практиці науково-методичного забезпечення фрормування готовності до усвідомленого батьків- 
ства студентів закладів вищої освіти; спонукання студентів до здійснення систематичного самовиховання у вказаному напрямі. Наступним кроком буде проведення експериментальної перевірки ефективності цих умов.

\section{БІБЛІОГРАФІЧНИЙ СПИСОК:}

1. Антонович О.С. Формирование психологической готовности родителей к взаимоотношению с будущим ребенком : дис. ... канд. психол. наук: 19.00.07. Самара, 2009. 250 с.

2. Бражнич О.Г. Педагогічні умови диференційованого навчання учнів загальноосвітньої школи : дис. канд. пед. наук: 13.00.07. Кривий Ріг, 2001. 238 с.

3. Губский Е.Ф Философрский энциклопедический словарь. Губский Е.Ф., Кораблева Г.В., Лутченко В.А. М. : ИНФА. 1998. 576 c.

4. Дурманенко О.Л. Теоретичний аналіз поняття «педагогічні умови» в контексті моніторингу виховної роботи у вищому навчальному закладі. Молодь $і$ ринок. № 7 (90). 2012. С. 135-138.

5. Евдокимова Е.В. Формирование ценностного отношения к родительству у студентов вуза : дис. ... канд. психол. наук: 19.00.07. Пятигорск, 2015. 211 с.

6. Карпичев В.С. Организация и самоорганизация социальных систем: словарь. Российская академия гос. службы при Президенте РФ. М. : Издательство РАГС, 2001. 125 с.

7. Куликова Т.А. Формирование готовности будущего педагога к профрессиональной деятельности. Куликова Т.А., Пронина Н.А. Вестник ТГПУ (TSPU Bulletin). 2018. 3 (192). C. 84-90.

8. Лемещенко О.Р. Соціально-психологічні умови формування у старшокласників готовності до усві- домленого батьківства : дис. ... канд. психол. наук: 19.00.05. Сєвєродонецьк, 2016. 224 с.

9. Лиховцов С.Е. Система научно-методического обеспечения подготовки специалиста технического профриля в системе СПО. Теория и практика образования в современном мире : материалы IV Междунар. науч. конфр. СПб : Заневская площадь, 2014. C. 144-147.

10. Манько В.М. Дидактичні умови фрормування у студентів профресійно-пізнавального інтересу до спеціальних дисциплін. Соціалізація особистості : зб. наук. пр. Національного педагогічного університету імені М. Драгоманова. К., 2000. Вип. 2. С. 153-161.

11. Овчарова Р.В. Родительство как психологический феномен : учебное пособие. М. : Московский психолого-социальный институт. 2006. 496 с.

12. Повалій Л.В. Формування у старшокласників відповідального батьківства як сімейної цінності. 2015. Young Scientist, № 2 (17). C. 291-294.

13. Тіунова О.В. Психологічні умови фрормування відповідального ставлення до материнства у дівчат старшого шкільного віку : дис. ... канд. психол. наук: 19.00.07. Тернопільський національний педагогічний ун-т ім. Володимира Гнатюка. Т., 2008. 262 с.

14. Хавула Р.М. Психолого-педагогічні чинники формування психологічної готовності юнаків до батьківства. Проблеми сучасної психології : Збірник наукових праць Кам'янець Подільського національного університету імені Івана Огієнка, Інституту психології ім. Г.С. Костюка АПН України. 2010. Вип. 10. Кам'янець Подільський : Аксіома. С. 771-781.

15. Яременко В. Новий тлумачний словник української мови: у 4 т. Яременко В., Сліпушко О. К. : Аконіт, 1999. T. 2. 910 C. 